ARTICLE

DOI: $10.1057 /$ s41599-017-0057-5

\title{
The body politics of the urban age: reflections on surveillance and affect
}

Ola Svenonius (iD ${ }^{1}$

\begin{abstract}
The article theorizes surveillance and affect in the context of urban security policy. Surveillance, as commonly understood, provides the means to "know" a person or a population, and to a certain extent to control or manage her/him/it. Hence, surveillance and knowledge are intimately tied together. New modes of surveillance are, therefore, also contingent upon new ways of knowing. This article discusses surveillance and affect in urban politics and let these concepts communicate with empirical research on urban security. The starting point is empirical research in three European cities on changes in local level security policy between 2000 and 2010. In all three cases, significant changes in the governance networks' approaches about security were observed. These changes coincided with new developments in the use of surveillance technologies to increase feelings of security. In this process "performative" surveillance became a central aspect of urban security policy, with particular focus on affects related to fear of crime, old age, and gender. The article theorizes the relationship between security, surveillance, and affect. The argument put forward is that new security policies were instances of the production of a discourse in which the precognitive, instinctual affects were increasingly targeted. The article shows how proponents of the new type of security governance articulate policy goals focusing on fear, threat, and surveillance. It contributes to a small body of literature on urban security and emotions by showing how cultural differences play out when similar policy goals that target citizens on the level of pre-cognitive affects are implemented.
\end{abstract}

\footnotetext{
${ }^{1}$ Department of Political Science, Stockholm University, Stockholm, Sweden. Correspondence and requests for materials should be addressed to O.S. (email: ola.svenonius@statsvet.su.se)
} 


\section{Introduction}

rban security governance is arguably one of the main challenges in an age where more people dwell in cities than in rural areas. Terrorism, violent crime, theft, and drug-related crime are all problems with a distinctive urban flair (Bugliarello, 2003; UN-HABITAT, 2012). How cities, sectoral public authorities, and public contractors organize their response to crime and other security issues is the subject of local security policy and governance. Priorities may change rapidly with the more general security environment, but urban studies research shave shown a general shift toward making perceptions a main object of urban governance (Taylor Buck and While, 2017; Helms et al., 2007; Pain, 2009; Raco, 2003; Svenonius, 2012). In Europe and North America, three aspects of local security policy are shared between most cities: a focus on security as an experience, the body as the site of this experience, and visual surveillance as the tool to render bodies more transparent and manage threats against them (Galdon-Clavell, 2015; Lippert, 2012; Tulumello, 2017). In this article, I address these points from a perspective of local security policy and affect. I discuss ways in which bodily intensities have become an object of security policy in western cities and how it functions to promote the increasing use of visual surveillance technologies.

Since the mid-1990's there has been an ever-increasing use and technical development of video surveillance technologies. Cities and law enforcement agencies have been keen on applying the new technologies, hoping that they would help to prevent crime and increase security (Graham, 2001; Hempel and Töpfer, 2004; Webster et al., 2012). Despite these hopes never actually materializing, cities and police departments keep investing in surveillance systems (College of Policing, 2013; Firmino et al., 2013; Spiller, 2015). Why is this so? One answer to this question is that pictures help police in investigating crime, that courts tend to favor video surveillance images as evidence over witnesses, or that surveillance systems makes it easier to react to emergency callsin short, that security governance networks increasingly depend on surveillance in their everyday practices, as Germain et al. (2011) argue. Another proposition, which I develop in this article, is that video surveillance has become part of a policy discourse that takes peoples' affects as the main objective for security governance, and in which security measures are evaluated in terms of their reassurance function.

The text is structured as follows. First, I discuss the background of this text and what contribution it makes to research on surveillance and urban governance. I discuss the notion of affect and subsequently develop an account of surveillance and affect. I argue that there is a lack of internationally comparative research in the literature on affect, which is unfortunate because comparison is potentially highly rewarding for this line of theory. Finally, I apply this discussion on security governance in three European capitals' public transport systems. A concluding note discusses the contribution and provides an outlook for future research.

\section{Background}

In 2006, the Stockholm public transport authority $A B$ Storstockholm Lokaltrafik introduced "the Security Project" (Trygghetsprojektet), which was a comprehensive reorganization of the system of governance in the public transport. Competences were centralized to the SL headquarters and away from private contractors, security staff were trained to be more service-minded, a new language of security was introduced, and a vast system of ca. 20,000 surveillance cameras were installed as the technical backbone of the system. At the same time, efforts to develop security measures in Berlin and Warsaw headed in a similar direction, only using slightly fewer cameras. ${ }^{1}$ In both Berlin and Warsaw, surveillance capacities of the city, the police, and the public transport authorities were increased significantly in the period between 2005 and 2010. In these three contexts, which are rather different in terms of how security is organized and regulated, and in terms of political history, one aspect stands out: In all cases security measures were being introduced not only because of their alleged efficiency to reduce threats or prevent crime, but because of their impact on public perceptions about security. ${ }^{2}$ In Warsaw, there was even indications that the systems were introduced because they represented alignment with the West and were considered to be "cool" (Björklund, 2013; Svenonius, 2011). Instead of evaluating security measures' effectiveness on crime and disorder, policy goals were set with respect to subjective feelings of security and comfort. While thinking about security in terms of "subjective" and "objective" is not in itself new, law enforcement and the transport sector focused mainly on the objective side until recently, assuming that subjective security was a function of the objective level of threat. Further, this change in local security policy is in itself not exclusive to these three cases, but represents a more general development in urban security governance in Europe and North America (Taylor Buck and While, 2017; Persson, 2014; Sinkienè et al., 2013; Sleiman and Lippert, 2010). The 2006 "Security Project" was thus an indication of a much larger shift in security governance in this part of the world.

These cases have been analyzed elsewhere, in terms of political norms, internal legitimation of surveillance, and discourses of security (Svenonius, 2011, 2012, 2017). Here, I expand on the issue of what these security reforms were aimed to achieve, and how security challenges were met. I do this from the perspective of affect, which is a concept that has been popular in cultural studies and social science for some time. Only recently has it emerged in political science, mainly in international relations theory (see e.g., Di Gregorio and Merolli, 2016; Hall and Ross, 2015; Leese and Koenigseder, 2015). ${ }^{3}$ This article grew out of previous empirical work, and I draw on interview data and public documents to illustrate the argument forwarded below. ${ }^{4}$ The first step is to outline my understanding of affect and emotions.

\section{Affect}

Affect theory gained popularity in cultural studies and philosophy after the publication of Eve Kosofsky Sedgwick \& Adam Franks' Shame in the Cybernetic Fold (1995) and Brian Massumi's The Autonomy of Affect (1995). In time this line of theory became increasingly popular also in the social sciences. Some enthusiastically hail this development as "the affective turn" (Clough and Halley, 2007; Featherstone, 2010) representing a shift away from language and to the body as site of academic inquiry (Ahmed, 2004; Turner and Stets, 2005; Wetherell, 2012). Affect can thus be understood as part also of another "turn", i.e., that to materiality (Coole and Frost, 2010). This section introduces affect theory and subsequently goes on to discuss affect and surveillance.

Affect theory concerns the pre-conscious aspect of social relations-bodily sensations in on the verge of consciousness. It has been used to explain the success of seemingly incompetent politicians such as Ronald Reagan, and offers political science an insight into the intersubjective mechanisms that define elusive concepts such as "charisma", "logic of appropriateness", and "fear" (Massumi, 1993, 1995). Equally as with the concept of emotion, there is no generally accepted definition of affect, and several different "schools" use the concept quite differently (Ahmed, 2004, p 5; see Thrift, 2004 for an overview). While in common language a person can be "affected" or act "in affect", 
this is of only partial relevance to the theory discussed here. Instead affect theory focuses on bodies' capacity to affect and to be affected by others. Affect is thus a relational concept, shifting the focus from the individual's culturally defined emotions to the more fluid and temporary affects that travel between people (Ellis et al., 2013; SFB Affective Societies, 2016).

Among the first to use the concept of affect was Silvan S. Tomkins, who in the 1950's began studying the immediate reactions to external stimulus in babies from a cybernetic perspective. Tomkins reached the conclusion that there are nine "affects" that are hardwired in the human body, i.e., independent of cultural context. ${ }^{5}$ According to Tomkins, humans strive to maximize positive affect (enjoyment and interest). ${ }^{6}$ The system of affects in Tomkins theory is separate from the drives that are studied in psychoanalysis, whereby the affects provide the immediate information that is then disseminated by the "drive system" and made conscious in shape of emotions (Tomkins, 2008, p xiv). From my perspective, Tomkins' theory of affect resides in the gray area between materiality and social construction, which is key to the understanding of affect theory in general. ${ }^{7}$ Later work, most notably by Brian Massumi $(1995,2002)$, has developed a more philosophically oriented understanding of affect informed by Spinoza's Ethics and Deleuze and Guattaris' work on e.g., assemblages. The point of departure is a critique against the Cartesian division between mind and body, which has been central to European thought since the Enlightenment. Affect in this understanding is a form of "body thought", highlighting the inseparability between (rational) thought and sensation (e.g., skin touch and fear). Although Massumi and others avoid defining affect and instead ask what it "does", one can define it as a relational intensity, unsignified and vanished before it can be labeled as an emotion. ${ }^{8}$ Consider for example the "gut feeling" of something "being in the room", or the chilling sensation of a sudden scare. ${ }^{9}$ These are unmediated experiences whose becoming is difficult to discern but which are very pertinent once they appear. Affect directs attention to miniscule movements and sensations of the body and face, whose potential capacity to become affected and power to affect others is what defines it as human (Gregg and Seigworth, 2010, p 2). In the instant that the subject labels these feelings they are filtered through culture or discourse, and appropriated by the subject as what we call an emotion (SFB Affective Societies, 2016; Turner and Stets, 2005). To theorize affect in this quasi-material understanding means to grapple with the diffuse area between materiality and construction; between molecules, cells, and body on the one hand, and perception, emotion, and culture on the other.

There are two characteristics of affect that are essential: first, it's intersubjectivity, and second, the distinction between affect and emotion. I discuss these briefly in turn. Beginning with the former, in the description above I portrayed affect as a sensation in an individual body. In fact this is an over-simplification, because the very essence if affect is its transmission and its intersubjectivity. Sensations are not a thing that people "have", but something that passes through and is mediated by the body. Consider, for example, the contagiousness of yawning, the collective tension in the bodies of a group of engaged people watching an important sports event, or the fear one may experience seeing someone else being terrified. In such circumstances, even subjects who are not afraid, tired, or interested in sports easily get "gripped" by intensities of others. Indeed, the notion of "contagent emotion" is just as suitable for affect; Sarah Ahmed even describes affect and emotions in terms of "affective economies" where the power affect draws its effect not mainly from the original impulse, but from the movement between persons (Ahmed, 2004: 44ff). Much of politics and consumer culture is oriented toward the transmission of affect, for example, the instinctive trustworthiness of a charismatic leader, or the subjective embarrassment on behalf of others that many experience while watching people expose themselves on reality TV. ${ }^{10}$ Thus,

"affect is found in those intensities that pass body to body (human, non-human, part-body, or otherwise), in those resonances that circulate about, between, and sometimes stick to bodies and worlds, and in the very passages or variations between these intensities and resonances themselves." (Gregg and Seigworth, 2010, p 1)

Despite the vagueness this quote is significant. It means that affect is not something that exists solely in the body, but between and around human bodies, animals, and may be also artefacts. "Fear was in the air", is a common phrase and it highlights the non-exclusiveness and collectivity of affect. For the purposes of this paper this is essential.

Second, the question regarding the relationship between emotion and affect. ${ }^{11}$ In the above I write that affect is that which has not yet been labeled with emotional content, and this pinpoints the difference between affect and emotion. If emotion is affect that is durable and evident enough to be consciously registered and identified as an emotion, this means that a stimulus has become "secondary", i.e., passed through our cognitive filters, which are defined by culture, identity etc. When an experience is identified and labeled as, for example, "nervousness" or "anxiety", this represents a discursive construction. The experience is contingent on specific conditions of possibility, which means that it could easily be interpreted differently in another time and place (Hunt and Wickham, 1994: 119f). It follows that affect-the non-signified-exists outside of discourse. Following Tomkins' theory, affect is hardwired in the human body; Massumi's affect intensifies in the body but is not necessarily part of it. The difference is irrelevant here because the key argument is that affect in both cases may be non-conscious, nonarticulated sensations in an abstract, shifting world. They are "primary" emotions: before, outside, and perhaps even beneath discourse (cf. Stavrakakis, 2007, ch. 2). Emotions on the other hand, are "secondary" in traditional social psychology (Turner and Stets, 2005: 13ff). They are subjected to the specific norms, habits, and ways of knowing that characterize discursive subjectivation. Governance of affect implies that citizens' perceptions become the object of security policy and included in the calculation.

\section{Discipline, surveillance, and affect}

The intensities described by affect theory are strongly related to urban surveillance. The surveillance studies have traditionally understood affect indirectly, most notably through the works of Michel Foucault, and in particular his notion of the panopticon as presented in Discipline and Punish (Foucault, 1977). According to Foucault, the panopticon was a diagram for disciplinary power in society in general, and it worked by the smallest of sensations. It was not necessary that the subject (the inmate, the worker, the student) consciously felt the constricting effects of surveillance, nor was it that s/he felt fear and anxiety as a result by it. Important was that as $\mathrm{s} /$ he is made aware of and feels the potential of surveillance. The experiences is essentially corporeal and not a product of reason:

"He who is subjected to a field of visibility, and who knows it, assumes responsibility for the constraints of power; he makes them play spontaneously upon himself; he inscribes in himself the power relation in which he simultaneously plays both roles; he becomes the principle of his own subjection." (Foucault, 2003: 202f, italics not in original) 
The spontaneity makes brute force redundant in the panoptic diagram. Affect theory offers a way to understand the mechanisms of disciplinary surveillance. This is even more clear in connection with body and knowledge, such as in the "technologies of the self" that Foucault discussed in his History of Sexuality I and which rely on the internalization of specific ideals in a subject's body image (cf. Featherstone, 2010). Contrary to the psychoanalytic notion of the subconscious that serve as a domain for repression of emotions, the pre-conscious is not a site for repression but for enhancement, reproduction, and distribution. Disciplinary power in this form functions by the minuscule movements, hesitations, and glances that subjects involuntary and non-consciously perform in everyday situations, which nevertheless have important social effects. ${ }^{12}$ If discipline moves the body through affect it becomes easy to understand how emotions of security and insecurity can emerge non-consciously in social interactions, even in subjects who would not designate themselves as anxious. Affect theory provides a way to enhance our understanding of disciplinary power, but also a way to move beyond Foucault because it allows us to lift off some parts of the very heavy conceptual apparatus that always risk becoming a life of its own in Foucaultinspired work (see again Kosofsky Sedgwick and Frank, 1995).

Contemporary works on surveillance and affect were until recently, as noted by Ellis et al. (2013, p 724) "few and far between". Today there are more contributions in this field of study, though it still is not a coherent literature. Existing works focus either on perceptions of risk and security by urban dwellers or international security regimes. Adey's (2009) study of biometry and biopolitics at the airport is the only one that engages with public security and affect on a policy level. Adey looks at the use of biometric markers as part of a larger surveillance assemblage in aviation security, and foremost how the human face and its expressions are made into regulatory space. He shares this approach with Leese and Koenigseder (2015) who discuss humor and airport security. Others seek to explain international politics by letting affect theory constitute the micro-foundations for political behavior (Hall and Ross, 2015; Hutchison and Bleiker, 2014). Van Rythoven (2015), for example, attempts to marry affect theory with securitization, and argues that relational affects facilitates securitizing moves. In urban studies, researchers have analyzed the precariousness of security and surveillance, from a gender perspective (Koskela, 2002), fear of crime more generally (Brands et al., 2015; Brands and Schwanen, 2014; Shaw, 2014), and in public transport (Bissell, 2010). Ellis et al. (2013), for example, develop the concept "affective atmosphere" in a study on British citizens' understanding of CCTV surveillance. Their study is a good example of theorizing in this line of research: the atmosphere concept aims to capture the relational intensities of feeling that i.a. Massumi (2002), Thrift (2004), and Featherstone (2010) discuss, but despite the eloquent theoretical work by the authors it is of limited utility due to its complexity. On a general level, these are all more or less critical studies that discuss the contingencies of security and surveillance from a perspective of affect. It is an interesting observation that none of the existing works on affect applies a comparative design, which is remarkable because of the importance of the discursive vs. pre-discursive distinction for this line of theory. In this article, I move in between the levels of the works cited above and apply a policy perspective in the context of urban security governance. I contribute to this literature by showing how an affect-centered security policy was introduced in three different cases and how it affects the response to security problems in practice.

\section{Surveillance in public transport}

The above discussion is an attempt at conceptualizing affect and surveillance in a more parsimonious way than previous works have done. Either the concept is over-theorized in Massumi's tradition, or it is reduced to more or less a synonym of "emotion", as some of the works in political science cited above. What I want to achieve here is to take the two points on affect that I stressed above-its interpersonal and pre-cognitive characterand apply them to urban security policy in the transport sector. What follows is a theoretical endeavor; a line of reasoning based on earlier research that argues that insights from these particular cases contribute to affect theory. The argument that I make is that the security reforms implemented the panoptic diagram by taking peoples' affects as their prime object of interest. The general use of cameras to affect passengers' bodies exist in all three cases, but in each case the way that security measures are designed not only tells us something about how governance by affect functions in practice, but also how we can think about reciprocity between culture and affect. I begin by discussing the change in security policy in the three cases. Later I continue with a discussion on what these changes mean and how governance by affect works.

The security policies in Berlin, Stockholm, and Warsaw at in the 21 st century all follow a similar pattern: In an environment characterized by a high-degree of physical safety, focus now lies on how safe passengers feel, and in all three cases the public transport systems are almost completely monitored by surveillance cameras. The movement from focusing mainly on what can be labeled as "operational" security, like fires and accidents, began in the late 1990's and early 2000's, and was accompanied by a new interest in and measurement of attitudes to security among the passengers in order to increase ticket revenue. There were several reasons for this: new terrorist threats, demands for increased security for employees by trade unions, rapid technological development, organizational changes, and a "fertile soil" (SL security mgr, 12 August 2008) for increasing surveillance, to name a few. Security managers in all three cities mention a shift in mentality with respect to surveillance somewhere around 2000-2005 (BVG communication mgr, 06 March 2009; SL security mgr, 12 August 2008; Stockholm transport police mgr, 03 August 2010; TW operations mgr, 17 December 2009; VBB security mgr, 13 September 2009; ZTM Security \& PR mgr's, 16 December 2009). ${ }^{13}$ While it is not my aim to explain the emergence of the new security policy but to interpret its intentions in light of the discussion above, it suffices to say that previously all transport authorities focused predominately on reducing the risk of accidents. In the early 2000's (in the Warsaw case later), the previous way of working with security was supplemented by new methods of measuring perceptions among the passengers that built on a new set of assumptions about how to govern the transport sector in their respective cities. For example, it was revealed that many women and elderly people felt very uneasy traveling in urban areas (BVG communications mgr, 06 March 2009; SL security mgr, 12 August 2008). On this backdrop, video surveillance became one of the main instruments to improve passengers' feelings of security. By the end of the decade, urban public transport authorities and city councils had all changed the ways in which they measure corporate success and how they communicate security issues. Today the focus lies very much on perceptions of security as the main policy goal, because of the impact on customer satisfaction.

Stockholm. To exemplify the change in policy that developed within a few years in the early 2000's, we first look at the Stockholm transport authority AB Storstockholms Lokaltrafik (SL) security policies. The first available policy is from 2003 and consists of a four-page document without any particular layout or 
product design. This document lays down the policy goals for the SL bus traffic as follows:

"The overarching goal is that the SL should always offer passengers and employees a safe and secure public transport. Passengers should think of public transport as the safest alternative. The goal is that no passenger or employee shall be killed or seriously injured in or as a result of the SL bus transport." (Stenbäck and SL, 2003)

Less than 2 years later, the SL published its new "Strategic Platform 2005-2015", which is a completely different type of document. Thoroughly designed, it spans over 50 pages and includes detailed plans on how to make the SL public transport more attractive. To achieve this, 15 goals with indicators are set, of which several related to security. Here, the goals are formulated quite differently:

Goal \#4-Improving the transport environment: “The SL's image is strongly influenced by the feeling that the SLenvironments transmit as to the passengers. This applies to stations, bus terminals, and the vehicles that we use. Design, light and colors, artwork, signs and service are important factors. Cleaning of vehicle and other areas that passengers use and comfort is also part of the experience. Equally important is a nice and service-minded approach by the staff."

Goal \#6-Increasing security: "Experiences of security are the result of a combination of absence of accidents, threats and violence, and the effects of i.a. lights, graffiti and damages, camera surveillance etc. Presence of visible staff in the SL traffic significantly increases the feeling of security." (SL, 2005: 36f)

These two documents transmit very different worldviews with respect to security. While the first does include subjective notions of security, its main message is that no one should get killed or injured. Focus lies quite clearly on security as absence of physical harm. The latter document has developed this idea to a quite different dimension, which was confirmed during interviews with the SL security manager at the time (SL security mgr, 12 August 2008). The object of SL security ambitions is now set on feelings, and actual threats are mainly relevant to the extent that they affect how passengers feel. Even these brief passages display well the changed approach of the transport authority-bodies and innate objects now transmit sensations that circulate among passengers and the ambition is to direct those sensations in accordance with SL overarching goals of an increasing market share. ${ }^{14}$

The Security project was presented to passengers in a brochure in 2006, which further develop the impression above. In the brochure, the reader is informed about the merits of video surveillance to curb insecurity, and pictures throughout show who is the target group of the message:

An elderly woman walks alone in a subway station. It's daytime. She looks a bit anxious and lost; she may not be able to cope with the speed of things in the environment. People rushing, entrance gates snapping shut, displays relaying a lot of information. Busy young people nearby take no notice of her. There is no visible threat, yet she looks insecure.

[Author's interpretation of image in the brochure "The Security Project" (SL, 2006, p 1)]

This is not quite accurate, however. The security division at the SL were very aware of the fact that many young people also were not comfortable in the public transport, but the idea was to treat the passenger collective like the lady in this picture and thus ensure that everybody felt "cared for" (SL security mgr, 26 February 2009). Assisting the police and the actual crime reduction is thereby of secondary importance, as stated by the SL communications manager in a later interview in 2010:

"It's not our primary [goal] to make sure that the police can fight crime; rather that's like, it's like a positive spin-off of the whole thing. It's just to make our passengers to feel secure. Passengers and staff should feel secure in the system" (SL communications mgr, 05 March 2010)

The SL security policy had thus developed from a basic commitment to absence from physical harm to the much wider attention to passengers' affects and emotions. In Berlin and Warsaw, similar processes can be observed.

Berlin. In Berlin, the security policy explicitly distinguishes between "subjective" and "objective" security already in 1999 (Abgeordnetenhaus von Berlin, 1999). The German state rail operator Deutsche Bahn AG that operates the Berlin commuter trains through a subsidiary, S-Bahn Berlin, launched a nationwide security policy in 1994 that included video surveillance. The policy was very restrictive in terms of data access and recording hours (Spörl, 1999). It was labeled " $3-S^{\text {”15 }}$ and was considered as a gold standard in privacy-sensitive security practice in Germany due to the fact that while there was video surveillance, only the police had on-site access to the footage. ${ }^{16}$ The 3-S policy became a unitary approach not only to security, but all aspects of customer experience. It inserted passengers' perceptions of service and cleanliness into the equation of security while at the same time assisting the police with law enforcement and crime prevention. In the beginning it was centered on "objective security", but later developed to become more perception-based (DB Station \& Services 3-S mgr, 06 May 2009. It can be considered a hybrid model between an "affect-" and an "operations-centered" approach.

In the German case the federal political system, cross-state operations, and diverse ownership structures makes the Berlin public transport governance a very complex matter. The Berlin security policies are codified in the Berlin senate's Local Transport Plan (Nahverkehrsplan), which are renewed by the Senate Department for Urban Development and Housing (SenStadt) ${ }^{17}$ roughly every 4 years. However, these are specified in security policies by other actors, such as the Berliner Verkehrsbetriebe (BVG) and the interstate transport authority Verkehrsverbund Berlin-Brandenburg (VBB). While the Local Transport Plan outlines the basic direction and minimal expectation, the operators and other actor may go further on particular issues. Here, we look mainly at the political documents. In the section on security the 2001 Local Transport Plan states that:

"Vehicles and facilities in the public transport system shall be designed in such a way as to ensure the actual safety from crime and harassment and that the subjective perception of security is influenced in a positive direction. Beyond this preventive and side measures [flankierende Maßnahmen] to increase safety/security shall be taken." (SenStadt, 2001, p 82)

This portal passage brings up the fact that there is an "objective" and a "subjective" side to security but treats these as equally important. The BVG and SenStadt was already a this point discussing an expansion of video surveillance, which was in place but in small scale at the time (Abgeordnetenhaus von 
Berlin, 1999). However, in the $2006-2009^{18}$ Local Transport Plan, this passage transformed into the following:

"Personal security determines satisfaction and passenger demand considerably. In addition, aspects of gender equality ("gender mainstreaming") [sic] and the concerns of older passengers deserve special attention. There is less need for action with regard to objective safety parameters but, above all, the safety subjectively perceived by the passenger" (SenStadt, 2007, p 119)

Thus, the more modest formulations in the 2001 Plan had been replaced by a near exclusive focus on security as affect one generation later. This formulation was kept and is almost identical in the current Plan (2014-18). In the 2006 document, the issue area had also been specified further by the emergence of gender mainstreaming as a policy field in Berlin, and a focus on the elderly that we recognize from Stockholm. It should be noted that this does not mean that operational security was of no concern to the public transport authorities, but that the priorities had been changed drastically during the period 2001-2007, when the 2006 plan was finished. The change in Berlin was thus directed by state politics, whereas in Stockholm, it was considered more of a project for the transport authority. ${ }^{19}$ But as the BVG public relations manager states: "We all know it-also the media -we all know that there is no objective... we have no objective problem. We do now and then, but it is a subjective problem. It's a feeling." (BVG communication mgr, 06 March 2009). The same focus on affect thus exists in the two cases, only the policy was more formalized from the beginning in Berlin.

Warsaw. In Warsaw, finally, the transport authority ZTM lacks a codified security policy. This does not mean that there is not a focus on perceptions and affect in the Warsaw public transport system, merely that the change initially occurred incrementally and less formally. Indoor cameras are installed when vehicles and facilities are renovated, and in one case the operations manager for the tram operator even stated that the producers of new vehicles installed extra cameras for free (TW operations mgr, 17 December 2009). The communications manager at ZTM described during the interview how the organization from ca 2007 has opened up and embraced a new way of thinking about public relations and security, including a focus on perceptions and image (ZTM communications mgr, 16 December 2009). However, with regard to the use of surveillance technology to achieve this aim, this is rather a matter for the police and the city's security bureau. ${ }^{20}$ Public security and crime prevention in Poland is the task of district administrations (powiat, one of three administrative levels in the country), and each district assigns a commission for public security and order. ${ }^{21}$ In order to locate the change to an affect-centered security policy it is, therefore, to the powiat's crime prevention policy that we must turn. Warsaw enjoys powiat status, much like Berlin is one of 16 German states, and it is the city's security policy that constitutes the relevant source of information.

The city of Warsaw has gone through a period of change since the year 2000, and just as in Stockholm, this occurred parallel to new measurements of public perceptions. ${ }^{22}$ However, the situation in Poland at the turn of the millennium was quite different, with substantially higher fear of crime rates (van Dijk et al., 2007). From earlier research and interview data we know that around 2000-2005 there was an extensive use of surveillance cameras in Warsaw, although not in public transport (Security bureau operations mgr, 17 December 2009; Svenonius, 2011; Waszkiewicz, 2011). The city relied on the security bureau and its monitoring capacity to prevent crime, but the Commission for
Public Security and Order did not formulate a security policy for the public until much later. The earliest document available is the inaugural statement for the year 2008, in which the Commission states that:

"The program is expected to be the basis for searching for and implementation of effective forms and methods, aimed at improving the security of Warsaw's residents and visitors in the city, as well as raising awareness and knowledge about how to avoid criminogenic situations. By determining areas of current threats and implementing appropriate response procedures there will be actions taken toward real improvement of the sense of security." (Komisji Bezpieczeństwa i Porządku, 2008, p 2)

Reducing crime and delinquency and raising awareness about how to avoid being victimized thus constitute the main policy goals in Warsaw around 2008-2010. It is in addition striking that the policy calls for action to "real improvement" in citizens' perceptions of security. Whereas the Berlin data repeatedly state that the "real" problem is conceptually distinct from the one perceived by passengers, this formulation conflates and equates the real with the perceived. This policy is quite technical and lacks the affect-centered characteristics of the more recent Berlin and Stockholm policies. The formulations above are similar to those in Berlin around 2001, which may indicate a time lag in Warsaw with respect to Berlin and Stockholm. Warsaw hitherto followed a slightly different path with extensive video surveillance in public spaces and lack of effective data protection regulation governing this practice (Pereira-Puga, 2013; Svenonius, 2017).

Since then the situation has changed, however. As with the early Stockholm policy, the 2008 document is an ordinary text without design effort or intention to be spread to the general public. However, the present policy, the "Secure Warsaw" program for 2016-2021, is different. It is more of a policy intended for a wider circle (although still rather technical), with hints of product design, explicit policy goals, and evaluative criteria. This policy, as in the other cases, now takes as its prime objective the increase in perceptions of security by the citizens (Rada m.st. Warszawy, 2017, p 5). The text begins with the following passage by mayor Hanna Gronkiewicz-Waltz:

"The sense of security is the basic need of man, which should be guaranteed because it is essential for her development. Its lack, or lack of satisfaction, does not allow for the realization of other important needs and hinders the work of the individual as well as of society as a whole. Security is the foundation of everything we do, it is the most important goal for every person and the whole of society. It covers the basic, vital needs of survival, stability and predictability, development, and finally human happiness." (Rada m.st. Warszawy, 2017, p 3)

As with earlier cases, this later document communicates a quite different worldview of, and approach to, security. Whereas like in Berlin, the earlier policy gave equal footing to objective and subjective security, the contemporary approach shifted its ambitions toward security as an experience and a human right (Ibid, p 5). So while the transport authority ZTM does not engage as actively in this area, the city administration clearly do. While the heavy reliance on technical surveillance in Warsaw may have been the focus of security efforts for some time, today the affectcentered approach is evident in all three cases.

In sum, I have shown that there has been substantial changes in the way that transport authorities and public sector security administrators conceive of security and the goal that they envision. These changes are substantial enough to quality a new set of ontological assumption about the world and how social 
change occurs. From a rather narrow operational focus the actors described in the above developed a wider conceptualization of security. It seems unlikely that they would have done so in isolation. International cooperation, new technological solutions, and international organizations such as the European Union may have a facilitating effect on these actors. This is outside the scope of this article. Below I continue the discussion and expand on what this change means for security governance.

\section{Discussion: governance of security as affect}

Discerning the change to an affect-centered security policy means that the authorities conceive of their principal task as one of increasing "subjective", "a sense of", or "perceived security". This does not automatically lead us to infer that the measures taken are directed to the pre-cognitive sensations and interpersonal affects discussed above. What does it mean for a transport authority or security commission to govern by affect, as opposed to govern by operative security, or even by secondary emotions? What are the commonalities? The answer to these crucial questions cannot be easily described because of case specifics. However, three factors related to visibility and esthetics are present in all three cases.

First, a highly visible "performative" surveillance becomes part of the everyday security provision. In all three cases, as stated above, modern video surveillance installations constitute the backbone of the affect-centered security. The difference between operative and affective security here lies in two aspects: The first is that today, authorities want to draw attention to the surveillance as much as possible, whereas before, the approach was for cameras to remain unknown so that offenders could be caught in the act and later arrested (Berlin data protection officer, CCTV division 05 May 2009). The previous approach builds on a policing logic, whereas the contemporary builds on an assumption of a disciplinary effect on offenders and a reassuring effect on other civilians. ${ }^{23}$ In the transport systems, the $\mathrm{BVG}$, and the city administration in Warsaw were for a long time reluctant to communicate their ongoing surveillance with signs, but pressure from data protection agencies and civil rights organizations, in combination with a new perspective on security, forced security managers to rethink this standpoint (BVG communication mgr, 06 March 2009; Panpotykon chair 18 December 2009). Today signage is an important aspect of security work and in all three cases, the authorities are anxious to communicate the fact that the transport systems are subjected to blanket-coverage surveillance. In the same way as the panoptic diagram exerts power spontaneously on the subject, so is the idea that public transport facilities and vehicles are controlled environments instructive for how affect-centered security works.

Second, promoting the visibility of security measures also run parallel to a more important role for public relations departments. In a "post-operative" security context, public relations becomes intimately involved in the security work in several dimension. Public campaigns in all three cities, have been used to increase awareness about security measures, such as surveillance cameras and security staff, as well as threats, such as pickpocketing. ${ }^{24}$ But communications departments also have the important task to inform passengers about disturbances and changes in the traffic. Uncertainty about where to go and when the next train arrives is an equally important factor as absence of physical threats and a clean environment, as the 3-S policy highlights. To this end the communications and security departments are today more intertwined than before. An elucidating example of this is that the BVG communications manager also participated in the interior design of new vehicles, and provided the more technically engineers with the passenger perspective (BVG communication mgr, 06 March 2009).

The public relations function of the transport authorities have also become "good news" media outlets under the affect-centered policy. Whereas the communication division in, for example, Berlin used to produce press releases with security statistics and oftentimes publish lists of security incidents on a daily basis, today they are reluctant to publish information that could provoke the impression that public transport facilities are unsafe. The communications departments consider local news media both as a blessing and a curse. The communications managers for the BVG, the SL, and the ZTM all discuss the problem of local "bad news" media that in their view tend to over-estimate the security risks and unjustifiably portrait public transport as insecure (BVG communication mgr, 06 March 2009; SL communications mgr, 05 March 2010; ZTM communications mgr, 16 December 2009). The communications departments, therefore, seek to control the flow of information to their advantage, and all have their own corporate outlets that are frequently used to highlight the efficiency and reliability of the security staff and surveillance cameras. The importance of communicating the right information at the right time is thus a major challenge in the affect-centered security landscape, and also serves to reassure passengers that they are cared for and not alone.

Third, and following from the first two points: the affectcentered security policy caused a shift in security staff aesthetics. In all three cases the transport authorities and public security administrations are highly aware of the signals that staff "emit" while working in public transport (cf. Innes, 2005). Not only does this mean a focus on cleanliness and service, but also the way that transport facilities are designed. In Berlin, for example, the BVG worked actively to commercialize platform space in the subway, among other things because a bakery or kiosk on the platform also ensures human presence (BVG communication mgr, 06 March 2009). A project was also initiated where long-term unemployed people were assigned to patrol the subway, "radiating" security by virtue of their presence (BVG, 2008a). ${ }^{25}$ In Warsaw, the private security company Skorpion, whose guards patrol the public transport system, are dressed in black uniforms that are strikingly similar to elite military troops or special operations police forces. According to the ZTM this is merely for show; they are "paper tigers", hired for psychological effect (ZTM security mgr, 16 December 2009). In Stockholm, finally, a completely different ideal was constructed in the course of developing the new security policy. The SL security manager describes his idea:

"I would like airline hostesses. [giggles] Not because they are beautiful, but because airline hostesses are basically supposed to have... they are very security minded, they are conflict managers, and they are determined. So that.. and they are service oriented, and that's what I want to attach to this [the security staff]."

\section{(SL security mgr, 12 August 2008)}

The same motive guides BVG new security mascot, "Betty", who exists on posters and film clips throughout the Berlin public transport system. Thus, depending on the cultural context, the security measures may look very different. In my reading from an affect perspective, this as a way to direct the pre-cognitive affects that travel to passengers from security staff. By adapting security aesthetics to "normal" cultural codes in a given society, the individual subject does not have to reflect on whether a guard "transmits" security or not-the risk of cognitive friction is reduced and a "circulation" of affect is made possible (cf. Thrift, 2004). 
In sum, the affect-centered security landscape is one in which the goal is to provide a seamless experience of public transport and/or city life where passengers instinctively know that someone is there and where potential wrong-doers are deterred from socially deviant behavior by the normative and disciplinary pressure of surveillance and social control. This is an environment that parallels Foucault's thought on the panoptic diagram, with one important difference: the passengers are not separated or compartmentalized. Instead, they exist as a collective of bodies and affects that flow through the transport system like water through a tube. The role of the supervisor is to ensure that the water keeps flowing and that any leaks are mended as soon as possible.

\section{Conclusions: surveillance, affect, and urban security}

Daytime in the subway, south Stockholm. A lot of people around. Suddenly there is commotion on the platform. People get a little tense. Into the subway wagon storms a gang of aggravated Nazi skinheads and hurl their bodies down on some empty seats. As the train departs passengers see two security guards on the platform, evidently happy to push their problem onto the train and get rid of it. Some passengers glance at each other. Nobody moves; everyone is completely quiet. The train is full of fear.

\section{[Author's notes from 12 August 2013]}

This unpleasant experience exemplifies the discussion above. The scene happened very fast, but affects travel instantly. After a while, we could all label our intensities as fear, though they still traveled between us passengers. At the same time the great disappointment about the "friendly" security staff that is very service-minded but could not manage a real threat as it occurred, and the video surveillance that-may be in a distant future could help the police with evidence of the beating-did not help any of us at all as the situation unfolded. In that moment, all the passengers wanted was a few Skorpion guards, I suppose.

In this article, I have discussed surveillance and affect in three cities. Based on a conceptualization of affect as interpersonal sensibilities and pre-cognitive impressions, I studied security policy changes in the Berlin, Stockholm, and Warsaw public transport systems. In all three cases significant changes to local security policies were identified that can be described as a shift in focus from operative- to affect-centered security. The new security policies seek to create an environment in which passengers feel safe to the point that they do not have to cognitively be aware of it. The policies look a bit differently in all cases, but share a priority of perceptions over "objective" security. In an attempt to theorize these cases, I suggested that performative surveillance, "good news" media strategies, and culturally adapted security aesthetics constitute the heart of the changes analyzed above. Especially the latter point constitutes a contribution to our understanding of affect, which is usually studied either as an abstract phenomenon or in single cases. The comparative approach of this article thus highlights both differences and similarities between three cases that allow us to reflect on affect and security in a novel way. Future research on affect should not shy away from comparative designs, because there is much still to learn in this area.

In a world of symbolic production, affects move to the center of modern security policy. Surveillance technology, notifications of their existence, and sublime architectural measures here enters into focus. This is especially relevant in the context of the Berlin, Stockholm, and Warsaw cases, where the meaning of "security" shifted from a focus on accidents to perceptions of security and wellbeing (Svenonius, 2011). This shift comes at a price, however.
Affects are, as I have argued, non-conscious and intersubjective intensities that have not yet been labeled with emotional status. By focusing on affect as measure of security, the transport authorities and political institutions legitimate wide-ranging video surveillance because of the proposed positive effect on feelings of security. The account above thus provides one piece of the puzzle as to why video surveillance is given such high priority among transport and police authorities.

Thereby it should be noted that affect is a complex and contextual phenomenon. There is no way to reliably predict how people will react to affect-oriented security measures. Some Varsovians may become less secure when Skorpion guards are around, and some Stockholmians may feel less secure under video surveillance because it symbolizes high-risk environments. Surveillance cameras and other security measures may produce different results based on the circumstances of each situation. In the example with the Nazis above, the guards were not at all helpful and the fact that they could not aid the passengers made us even less securehow were we going to make it if the security guards could not? In other words, the affect-centered security policy depends on a very efficient "operative" security that acts in the background.

Insecurity becomes not a function of actual threat but of potential anxieties, of collective intensities, of affect. Therefore, as the transport environment become safer and safer, new bodies and artefacts will emerge as threatening although they previously were not. Security may be a moving target and affect dependent on the context in which is appears. In this way, security measures become self-legitimating, as they (re)create their own problem. As soon as the operative security loses in efficiency the illusion of a seamless security crumbles. This reflection on surveillance and affect urges us to study the discursive nature of affect further, may be through experimental approaches, in order to grasp the nature of the pre-conscious and material effects of security discourse.

Surveillance, as commonly understood, provides the means to "know" a person or a population, and to a certain extent to control or manage her/him/it (see e.g., Haggerty and Ericson, 2006, p 6). New modes of surveillance, therefore, also represent new ways of knowing. Affect, in turn, has been discussed in terms of different ways of pre-conscious thinking, or as a mode of relational intensity (Massumi, 2002). Urban transport security is a very good example of how these concepts come into practice in contemporary urban environments.

Received: 23 June 2017 Accepted: 5 December 2017 Published online: 09 January 2018

\section{Notes}

1 Since these figure change continuously, it is difficult to estimate the current number, but in 2011 there were ca. 7000 cameras in Berlin and 3,750 in Warsaw (Svenonius, 2011, p 148). These numbers are today almost certainly inaccurate.

2 The efficiency of surveillance cameras is very contextual and a general deterrent effect on crime has not been scientifically validated. In Berlin, the only city of the three where crime statistics are reported exclusively with respect to the public transport system, assault rates has been rather stable throughout this period and afterwards. In the case of pickpocketing, the rate increased dramatically. This indicates that the actual crime rates are not significantly affected by, or dependent, on surveillance cameras, which is in line with earlier research on the topic (BRA, 2015; Waszkiewicz, 2013; Welsh and Farrington, 2002, 2007). See the supplementary materials for statistics on Berlin crime rates in the public transport system.

3 Searching for journal articles using the terms "affective turn" and "affect AND emotion" in political science on ProQuest and Web of Science (June 2017) yields no more than one hit-a special issue of Citizernship Studies on affective citizenship (Di Gregorio and Merolli, 2016).

4 Please see the supplementary materials for a note on methodological issues pertaining to the interview data and a complete list of interviewees. 
5 The nine affects are organized in dimensions (except the latst two) as follows: (1) Surprise-Startle, (2) Distress-Anguish, (3) Anger-Rage, (4) Enjoyment-Joy, (5) Interest-Excitement, (6) Fear-Terror, (7) Shame-Humiliation, (8) Dissmell, and (9) Disgust. No. 4 and 5 are positive affects, the rest are negative.

6 Later work in psychology identified similar mental states and labeled them "primary emotions" (Turner and Stets, 2005: 14f).

7 It is worth noting that this implies a non-determinant form of "analogous" essentialism in which a definite range of possible reactions exist, which Kosofsky Sedgwick \& Frank forcefully argue in their critique of Foucauldian "digital" analysis (either/or-thinking) that the authors see in some post-structuralist work.

8 Cf. Tomkins' understanding of the different affects as dependent on duration and intensity of "neural firing" as described in Kosofsky Sedgwick \& Frank (1995: 505ff).

9 This latter form of theorizing affect has proved very productive due to its openness, however abstract, and a multitude of understandings exist, for example, affect as body schema (Featherstone, 2010: 195f), co-enactment (Blackman and Venn, 2010, p 10), and time in matter (Ticineto Clough, 2010, p 229). In social psychology, affect is rather equated with emotion, or simply described as a "mood" (Forgas, 2001, p 14240).

10 In German, there is even a word for this latter transmission of shame: "Fremdschämen".

11 As Sarah Ahmed mentions, affect, emotion, feeling, cognition, and perception do not have stable definitions, neither between nor within disciplines (Ahmed, 2004, p 5).

12 See also Diana Coole's critique on social capital, which she describes in very much the same fashion (Coole, 2009). Coole's work opens for an interpretation of social cohesion in terms of affect, but this would be to stretch the concept a too far since it would then be difficult to separate from inherently problematic terms like "culture" and "discourse". The difference between affect and social capital in Coole's interpretation is that the emotion that she describes designate what I call "secondary emotions" (security, unease), which exist purely on a conscious level.

13 BVG: Berliner Verkehrsbetriebe (Berlin state transport authority); SL: AB Storstockholms lokaltrafik (Stockholm regional transport authority); TW: Tramwaje Warszawskie (Warsaw city tram operator) VBB: Verkehrsverbund BerlinBrandenburg (Berlin-Brandenburg interstate transport authority); ZTM: Zarząd Transportu Miejskiego m.st. Warszawy (Warsaw city transport authority).

14 It should be noted that the Swedish work used for security is "trygghet", which denotes both security and comfort or care (in a religious sense) (Eberhard, 2007).

15 “3-S” stands for Service (service), Sicherheit (security), and Sauberkeit (cleanliness). The policy is still in effect; see DB Station \& Service (2017).

16 This goes back to the difference between Videoaufzeichnung (recording) and Videoüberwachung (active monitoring) in German data protection regulation.

17 With the administrative reform of December 2016, this task was relocated to the Senate Department for the Environment, Transport, and Climate Protection. See http://www.berlin.de/sen/uvk

18 It was not finished until 2007, but still labeled 2006

19 The regional government in the Stockholm area (Stockholms läns landsting) was sympathetic to the Security Project in Stockholm, but they did not initiate it. Instead the SL and the police formed an alliance to persuade the politicians of the necessity of such an extensive system. See: Svenonius (2017, p 582).

20 Biuro Bezpieczeństwa i Zarządzania Kryzysowego Urzędu Miasta Stołecznego Warszawy.

21 Komisji Bezpieczeństwa i Porządku. This requirements stems from the 1998 act on powiat self-government, §38a (Kancelaria Sejmu, 1998).

22 The Warsaw Barometer, for example, includes several items on security and serves as evaluative benchmark for the city's security efforts. It was initiated in 2003. See: http://www.um.warszawa.pl/o-warszawie/warszawa-w-liczbach/barometr-warszawski

23 In criminology there has been a debate on "reassurance policing" for some time. See (Barker, 2017; Innes, 2007; Millie and Herrington, 2005).

24 See for example the "Don't be a carp! Don't get caught!" campaign against pickpocketing by the ZTM, the Betty and anti-violence campaigns by the BVG ("Halt Gewalt - Mach mit!"), and the Security Project campaign by the SL. These are described in Svenonius (2011, ch. 7).

25 The German term for this is Präsenzkraft (force of presence)

\section{References}

Abgeordnetenhaus von Berlin (1999) Mitteilung - zur Kenntnisnahme - über Sicherheitskonzept für den öffentlichen Personennahverkehr. Drucksache 13/4172

Adey P (2009) Facing airport security: Affect, biopolitics, and the preemptive securitisation of the mobile body. Environ Plan D: Soc Space 27(2):274-295

Ahmed S (2004) The cultural politics of emotion. Edinburgh University Press, Edinburgh

Barker A (2017) Mediated conviviality and the urban social order: Reframing the regulation of public space. Br J Criminol 57(4):848-866

Bissell D (2010) Passenger mobilities: affective atmospheres and the sociality of public transport. Environ Plan D: Soc Space 28(2):270-289

Björklund F (2013) Modernisation, balancing interests, and citizen's rights: Public video surveillance in Poland, Germany, and Sweden. In: Björklund F,
Svenonius $\mathrm{O}$ (eds) Video surveillance and social control in a comparative perspective. Routledge, Oxon, New York, p 19-68

Blackman L, Venn C (2010) Affect. Body Soc 16(1):7-28

BRÅ (2015) Kameraövervakning på Stureplan och Medborgarplatsen. Slutrapport. Report by the Swedish National Council for Crime Prevention. Wolters Kluwer, Stockholm

Brands J, Schwanen T (2014) Experiencing and governing safety in the night-time economy: Nurturing the state of being carefree. Emot, Space Soc 11:67-78

Brands J, Schwanen T, Aalst Ivan (2015) Fear of crime and affective ambiguities in the night-time economy. Urban Stud 52(3):439-455

Bugliarello G (2003) Urban security in perspective. Technol Soc 25(4):499-507

BVG (2008a) BVG setzt auf beides - Technik und Personal [BVG goes for both technology and staff]. - Das Kunde 4/5:6-7

BVG (2008b) Sicherheitsbericht der Berliner Verkehrsbetriebe (Appendix to Drs. 16/2231, Berlin Abgeordnetenhaus) [Security report of the BVG to the Berlin parliament, annex 16/2231]. Berliner Verkehrsbetriebe (BVG)

Clough P, Halley J (eds) (2007) The affective turn: theorizing the social. Duke University Press, Durham

College of Policing (2013) What works briefings: Effects of CCTV 2013. College of Policing, Coventry, Available from: http://www.college.police.uk/en/20720. htm. Accessed 3 Feb 2015

Coole D (2009) Repairing civil society and experimenting with power: A genealogy of social capital. Polit Stud 57(2):374-396

Coole D, Frost S (eds) (2010) New materialisms: Ontology, agency, and politics. Duke University Press, Durham [NC]; London

DB Station \& Service (2017) 3-S-Konzept. Deutsche Bahn AG. Available from: http://www.bahnhof.de/bahnhof-de/ueberuns/3-s-konzept.html. Accessed 26 Oct 2017

Di Gregorio M, Merolli JL (2016) Introduction: affective citizenship and the politics of identity, control, resistance. Citizsh Stud 20(8):933-942

Eberhard D (2007) I trygghetsnarkomanernas land: om Sverige och det nationella paniksyndromet [In the Land of the Security Junkies: on Sweden and the national panic syndrome]. Månpocket, Stockholm

Ellis D, Tucker I, Harper D (2013) The affective atmospheres of surveillance. Theory Psychol 23(6):716-731

Featherstone M (2010) Body, image and affect in consumer culture. Body Soc 16 (1):193-221

Firmino RJ, Kanashiro M, Bruno F et al. (2013) Fear, security, and the spread of CCTV in Brazilian cities: Legislation, debate, and the market. J Urban Technol 20(3):65-84

Forgas JP (2001) Social cognition and affect, psychology of. In: Smelser NJ, Baltes PB (eds) International Encyclopedia of the Social \& Behavioral Sciences. Pergamon, Oxford, p 14238-14242

Foucault M (1977) Discipline and punish. The birth of the prison. Vintage, New York

Foucault M (2003) Övervakning och straff. Arkiv Förlag, Lund

Galdon-Clavell G (2015) Uncivil cities: Insecurity, policy transfer, tolerance and the case of Barcelona's 'Civility Ordinance'. Urban Stud 53(9):1925-1941

Germain S, Douillet A-C, Dumoulin L (2011) The legitimization of CCTV as a policy tool: Genesis and stabilization of a socio-technical device in three French cities. Br J Criminol 52(2):294-308

Graham S (2001) CCTV: The stealthy emergence of a fifth utility? Plan Theory Pract 3(2):237-241

Gregg M, Seigworth GJ (eds) (2010) The affect theory reader. Duke University Press, Durham, NC

Haggerty KD, Ericson RV (eds) (2006) The politics of surveillance and visibility. University of Toronto Press, Toronto

Hall TH, Ross AAG (2015) Affective politics after 9/11. Int Organ 69(04):847-879

Helms G, Atkinson R, MacLeod G (2007) Securing the city: Urban renaissance, policing and social regulation. Eur Urban Reg Stud 14(4):267-276

Hempel L, Töpfer E (2004) Urbaneye Working Paper No. 15: CCTV in Europe Final Report. Berlin: Centre for Technology and Society. Available from: www.urbaneye.net

Hunt A, Wickham G (1994) Foucault and the law: towards a sociology of law as governance. Pluto Press, London

Hutchison E, Bleiker R (2014) Theorizing emotions in world politics. Int Theory 6 (03):491-514

Innes M (2005) What's your problem? signal crimes and citizen-focused problem solving. Criminol Public Policy 4(2):187-200

Innes M (2007) The reassurance function. Policing 1(2):132-141

Kancelaria Sejmu (1998) Ustawa z dnia 5 czerwca 1998 r. o samorzadzie_powiatowym. Kancelaria Sejm. Available from: http://bezpieczna.um.warszawa.pl/ sites/bezpieczna.um.warszawa.pl/files/Ustawa_o_samorzadzie_powiatowym. pdf. Accessed 20 Mar 2011

Komisji Bezpieczeństwa i Porządku (2008) Inauguracyjne posiedzenie Komisji Bezpieczeństwa i Porządku m.st. Warszawy. City of Warsaw

Koskela H (2002) Video surveillance, gender, and the safety of public urban space: 'Peeping Tom' goes high tech? Urban Geogr 23:257-278 
Kosofsky Sedgwick E, Frank A (1995) Shame in the cybernetic fold: Reading Silvan Tomkins. Crit Inq 21(2):496-522

Leese M, Koenigseder A (2015) Humor at the airport? visualization, exposure, and laughter in the 'War on Terror'. Int Polit Sociol 9(1):37-52

Lippert R (2012) 'Clean and safe' passage: Business improvement districts, urban security modes, and knowledge brokers. Eur Urban Reg Stud 19(2):167-180

Massumi B (ed.) (1993) The politics of everyday fear. University of Minnesota Press, Minneapolis

Massumi B (1995) The autonomy of affect. Cult Crit 31:83-109

Massumi B (2002) Parables for the virtual: movement, affect, sensation. Duke University Press, Durham

Millie A, Herrington V (2005) Bridging the gap: Understanding reassurance policing. Howard J Crim Justice 44(1):41-56

Pain R (2009) Globalized fear? towards an emotional geopolitics. Prog Hum Geogr 33(4):466-486

Pereira-Puga M (2013) Poland-A Surveillance Eldorado? Security, Privacy, and New Technologies in Polish Leading Newspapers (2010-2013). Prague SECONOMICS Discussion Papers, Prague: Prague Graduate School in Comparative Qualitative Analysis. Available from: http://www.soc.cas.cz/ sites/default/files/soubory/risks_and_security_in_spanish_newspapers.pdf. Accessed 9 Jun 2015

Persson M (2014) The dynamics of policy formation: making sense of feelings of public unsafety. Örebro university, Örebro, http://urn.kb.se/resolve?urn=urn: nbn:se:oru:diva-35087. Accessed 24 Feb 2016

Raco M (2003) Remaking place and securitising space: Urban regeneration and the strategies, tactics and practices of policing in the UK. Urban Stud 40 (9):1869-1887

Rada m.st. Warszawy (2017) Program zapobiegania przestępczości oraz porządku publicznego i bezpieczeństwa obywateli m.st. Warszawy na lata 2016-2021 (pn. "Bezpieczna Warszawa"). Rady m.st. Warszawy. Available from: http:// bezpieczna.um.warszawa.pl/sites/bezpieczna.um.warszawa.pl/files/program _ 2016_-_2021_wersja_z_25._02_2016_r_z_bp.pdf. Accessed 31 Oct 2017

SenStadt (2001) Nahverkehrsplan des Landes Berlin - Fortschreibung 2000/2001 und 2004. Senatsverwaltung für Stadtentwicklung, Abteilung VII Verkehr, Berlin

SenStadt (2007) Der Nahverkehrsplan - Berlin fährt vor! Nahverkehrsplan des Landes Berlin 2006-2009. Senatsverwaltung für Stadtentwicklung, Abteilung VII Verkehr, Berlin

SFB Affective Societies (2016) Affective societies - a glossary: register of central working concepts. SFB Affective Societies - Working Papers, SFB 1171 Working Paper 01/16, Berlin: Freie Universität

Shaw R (2014) Beyond night-time economy: Affective atmospheres of the urban night. Geoforum 51:87-95

Sinkienè J, Stankevičè I, Navickaitė K (2013) Creating safer cities through urban planning and development. Public Policy Adm 11(3):390-403

SL (2005) Strategisk plattform - Inriktning 2005-2015, 3rd edn. AB Storstockholms Lokaltrafik, Stockholm

SL (2006) Trygghetsprojektet: För ökad säkerhet och upplevd trygghet i SLtrafiken. AB Storstockholms Lokaltrafik. Available from: http://www.sl.se/csmedia/xyz/000023300.pdf

Sleiman M, Lippert R (2010) Downtown ambassadors, police relations and 'clean and safe' security. Polic Soc 20(3):316-335

Spiller K (2015) Experiences of accessing CCTV data: The urban topologies of subject access requests. Urban Stud 53(13):2885-2900

Spörl P (1999) 3-S-Programm. Service, sicherheit, sauberkeit. In: Rodemers, J and R Mokros (eds), Bahnhöfe. Sicherheit, Service, Aufenthaltsqualität. Institut für Landes- und Stadtentwicklungsforschung, Dortmund, p 106-109

Stavrakakis Y (2007) The Lacanian left: psychoanalysis, theory, politics. State University of New York Press, Albany

Stenbäck E, SL (2003) Trafiksäkerhet i SL:s busstrafik - Övergripande policy och mål. AB Storstockholms Lokaltrafik, Stockholm

Svenonius O (2011) Sensitising urban transport security: Surveillance and policing in Berlin, Stockholm, and Warsaw. Doctoral dissertation, Stockholm: Stockholm University, Department of Political Science. Available from: http://su.diva-portal.org/smash/get/diva2:456252/FULLTEXT01. Accessed 11 Feb 2013

Svenonius O (2012) The Stockholm Security Project: Plural policing, security and surveillance. Inf Polity 17:35-43

Svenonius O (2017) Legitimering av övervakning i lokal säkerhetspolitik. Statsvetensk Tidskr 3:465-503

Taylor Buck N, While A (2017) Competitive Urbanism and the Limits to Smart City Innovation: The UK Future Cities Initiative. Urban Stud 54(2):501-519

Thrift N (2004) Intensities of feeling: Towards a spatial politics of affect. Geogr Ann: Ser B, Human Geogr 86(1):57-78

Ticineto Clough P (2010) Afterword: The future of affect studies. Body Soc 16 (1):222-230

Tomkins S (2008) Affect imagery consciousness: The complete edition. Springer, New York
Tulumello S (2017) The multiscalar nature of urban security and public safety Crime prevention from local policy to policing in Lisbon (Portugal) and Memphis (the United States). Urban affairs review. https://doi.org/ 1078087417699532

Turner JH, Stets JE (2005) The sociology of emotions. Cambridge University Press, New York, NY

UN-HABITAT (2012) WORLD URBAN FORUM 6-The urban future. Concept paper. Nairobi, Kenya: UN-HABITAT

van Dijk J, van Kesteren J, Smit P (2007) Criminal victimisation in international perspective: key findings from the 2004-2005 ICVS and EU ICS. Den Haag: Boom Juridische Uitgevers; Wetenschappelijk Onderzoek-en Documentatiecentrum

Van Rythoven E (2015) Learning to feel, learning to fear? emotions, imaginaries, and limits in the politics of securitization. Secur Dialog 46(5):458-475

Waszkiewicz P (2011) Wielki Brat Rok 2010. Systemy monitoringu wizyjnego aspekty kryminalistyczne, kryminologiczne i prawne. Wolters Kluwer Polska, Warszawa

Waszkiewicz P (2013) How effective is the public video surveillance system in Warsaw? In: Björklund $\mathrm{F}$ and $\mathrm{O}$ Svenonius (eds) Video surveillance and social control in a comparative perspective, Routledge, New York, p 153-170

Webster CWR, Töpfer E, Klauser FR, et al. (eds) (2012) Video surveillance: practices and policies in Europe. Innovation and the public sector. IOS Press, Amsterdam; Washington, DC

Welsh BC and Farrington DP (2002) Crime prevention effects of closed circuit television. A systematic review. Home Office Research Study, London: Home Office Research, Development and Statistics Directorate. Available from: http://www.homeoffice.gov.uk/rds/pdfs2/hors252.pdf

Welsh BC, Farrington DP (2007) Kameraövervakning och brottsprevention: En systematisk forskningsgenomgång (Rapport 2007:29). Brottsförebyggande rådet (Brå), Stockholm, Available from: http://www.bra.se/extra/measurepoint/?module_instance $=4 \&$ name $=$ Kamera\%f6vervakning.pdf\&url =/dynamaster/file_archive/080111/12ale36b5d22dc5a16bf8f4aad7b4c5f/ Kamera\%255fsve\%255finlaga.pdf

Wetherell M (2012) Affect and emotion: a new social science understanding. SAGE, London

\section{Data availability}

The interview data generated and analyzed during the current study are not publicly available due to privacy of the interviewees but are available from the corresponding author on reasonable request.

\section{Acknowledgements}

This work was generously supported by the Foundation for Baltic and East European Studies (www.ostersjostiftelsen.se, grant number A051-12). We thank Dr. Michał Bron for his assistance during fieldwork in Poland.

\section{Additional information}

Supplementary information: accompanies this paper at https://doi.org/10.1057/s41599017-0057-5.

Competing interests:: The author declares no competing financial interests.

Reprints and permission information is available online at http://www.nature.com/ reprints

Publisher's note: Springer Nature remains neutral with regard to jurisdictional claims in published maps and institutional affiliations.

Change history: A correction to this article has been published and is linked from the HTML version of this article.

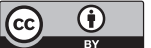

Open Access This article is licensed under a Creative Commons Attribution 4.0 International License, which permits use, sharing, adaptation, distribution and reproduction in any medium or format, as long as you give appropriate credit to the original author(s) and the source, provide a link to the Creative Commons license, and indicate if changes were made. The images or other third party material in this article are included in the article's Creative Commons license, unless indicated otherwise in a credit line to the material. If material is not included in the article's Creative Commons license and your intended use is not permitted by statutory regulation or exceeds the permitted use, you will need to obtain permission directly from the copyrigh holder. To view a copy of this license, visit http://creativecommons.org/licenses/by/4.0/.

(c) The Author(s) 2018 